Article

\title{
Using Advanced Spectroscopy and Organic Matter Characterization to Evaluate the Impact of Oxidation on Cyanobacteria
}

\author{
Saber Moradinejad ${ }^{1}$, Caitlin M. Glover ${ }^{1}$, Jacinthe Mailly ${ }^{1}$, Tahere Zadfathollah Seighalani ${ }^{1}$, \\ Sigrid Peldszus ${ }^{2}$, Benoit Barbeau ${ }^{1}{ }^{1}$, Sarah Dorner ${ }^{1}$, Michèle Prévost ${ }^{1}$ and Arash Zamyadi ${ }^{1, *}$ \\ 1 BGA Innovation Hub and Civil, Mineral and Mining Engineering Department, Polytechnique Montréal, \\ Montréal, QC H3T 1J4, Canada; saber.moradinejad@polymtl.ca (S.M.); caitlinmeara@gmail.com (C.M.G.); \\ jacinthe.mailly@polymtl.ca (J.M.); tahere.zadfathollah-seighalani@polymtl.ca (T.Z.S.); \\ benoit.barbeau@polymtl.ca (B.B.); sarah.dorner@polymtl.ca (S.D.); michele.prevost@polymtl.ca (M.P.) \\ 2 Department of Civil \& Environmental Engineering, University of Waterloo, Waterloo, ON N2L 3G1, Canada; \\ speldszus@uwaterloo.ca \\ * Correspondence: arash.zamyadi@polymtl.ca
}

Received: 26 April 2019; Accepted: 14 May 2019; Published: 17 May 2019

check for updates

\begin{abstract}
Drinking water treatment plants throughout the world are increasingly facing the presence of toxic cyanobacteria in their source waters. During treatment, the oxidation of cyanobacteria changes cell morphology and can potentially lyse cells, releasing intracellular metabolites. In this study, a combination of techniques was applied to better understand the effect of oxidation with chlorine, ozone, potassium permanganate, and hydrogen peroxide on two cell cultures (Microcystis, Dolichospermum) in Lake Champlain water. The discrepancy observed between flow cytometry cell viability and cell count numbers was more pronounced for hydrogen peroxide and potassium permanganate than ozone and chlorine. Liquid chromatography with organic carbon and nitrogen detection was applied to monitor the changes in dissolved organic matter fractions following oxidation. Increases in the biopolymer fraction after oxidation with chlorine and ozone were attributed to the release of intracellular algal organic matter and/or fragmentation of the cell membrane. A novel technique, Enhanced Darkfield Microscopy with Hyperspectral Imaging, was applied to chlorinated and ozonated samples. Significant changes in the peak maxima and number of peaks were observed for the cell walls post-oxidation, but this effect was muted for the cell-bound material, which remained relatively unaltered.
\end{abstract}

Keywords: cyanobacteria; oxidation; cell morphology; enhanced darkfield microscopy/hyperspectral imaging; intracellular organic matter

Key Contribution: This study is the first to use Enhanced Darkfield Microscopy with Hyperspectral Imaging to characterize the changes in cell spectra following oxidation with chlorine and ozone.

\section{Introduction}

Rising temperatures and the eutrophication of freshwaters have contributed to an increase in the frequency of cyanobacterial blooms [1-3]. Cyanobacterial cells are of concern because they can produce and release cyanotoxins as well as taste and odor $(\mathrm{T} \& \mathrm{O})$ compounds. T\&O compounds affect the aesthetic water quality, result in customer complaints, and lower the trust customers have in their water [4]. If ingested, cyanotoxins can cause gastroenteritis, cytotoxicity, liver damage, neurological effects and they have been linked to cancer, Alzheimer's disease and Motor Neuron Disease [5,6]. 
To protect customers, regulatory agencies have proposed and, in some cases, set health-based guidelines and threshold alert levels for both cells and their metabolites [7-9].

The removal of cyanobacteria and their metabolites is often a challenge for conventional water treatment (i.e., coagulation, flocculation, sedimentation and filtration) with both cyanotoxins and/or $\mathrm{T} \& \mathrm{O}$ compounds observed in finished drinking water [10-12]. However, cyanobacteria can also breakthrough filtration in water treatment plants considered to be of low risk, i.e., with low intake cell concentrations in their source waters, and high-risk, i.e., during bloom events $[10,13,14]$. Cyanobacterial breakthrough, particularly for low-risk plants, has been attributed to the accumulation of cells during treatment, e.g., in filter beds, in the sludge bed of sedimentation tanks, and in sludge thickeners $[10,13,15]$. Apart from the breakthrough of cyanobacteria and their metabolites, the presence of intracellular and extracellular organic matter (IOM and EOM) from algae, increases the coagulant demand and the formation of disinfection byproducts [16].

A number of studies have evaluated the oxidation (e.g., ozone, chlorine, potassium permanganate, and hydrogen peroxide) of cyanobacteria and their metabolites [17-21]. The impact of these oxidants ranges from cell damage to the release of metabolites through diffusion or cell lysis; the level of impact varies depending on the species of cyanobacteria present, presence of a slime layer, and the background water matrix, i.e., $\mathrm{pH}$ and background organic matter $[19,20,22,23]$. To model the release of metabolites, previous work has applied pseudo first-order sequential reaction rates to track the release of intracellular metabolites and the subsequent oxidation of the extracellular metabolites, i.e., intracellular-rate of release-extracellular-rate of oxidation-oxidized metabolites [24,25]. However, when model results have been compared with full-scale oxidation data, they often overestimate the oxidation efficiency $[17,24,26]$. In addition, the release of cyanotoxins and/or T\&O compounds can occur at very low doses (e.g., at detection limit for chlorine), making it very difficult to assess the potential risk during treatment $[27,28]$.

To better understand the changes in morphology that may be causing the discrepancy between expected release and actual release, previous work has used both Scanning Electron Microscopy (SEM) and Digital Flow Cytometry [20,29-32]. However, these techniques are qualitative and do not provide quantitative results. Enhanced Darkfield Microscopy with Hyperspectral Imaging (EDM/HSI) not only captures images of the sample, but also measures the visible wavelength spectrum (400-1000 nm) of each pixel. The black background in EDM allows the instrument to collect scattered light from the desired (i.e., cells) pixels of a sample. HSI has been used successfully to identify cyanobacteria blooms in laboratory and remote sensing applications [33-36]; however, it has not yet been applied to evaluate the impact of oxidation on cyanobacteria cells.

In this study, a combination of techniques was used to explore the impact of oxidation on cyanobacteria cells. The objectives of this study were as follows: (1) to quantify changes of two cyanobacteria in natural water following oxidation with chlorine, ozone, hydrogen peroxide, and potassium permanganate with flow cytometry, SEM, and liquid chromatography with organic carbon and nitrogen detection (LC-OCD-OND) and (2) to compare these results against the morphological changes observed with EDM/HSI after oxidation with chlorine and ozone. To the best of the author's knowledge, this study presents the first assessment of the morphological deformation of cyanobacteria after oxidation with EDM/HSI.

\section{Results and Discussion}

\subsection{Cell Viability Post-Oxidation}

Cultured cells (Microcystis and Dolichospermum) were spiked into Lake Champlain surface water prior to their exposure to chlorine, ozone, potassium permanganate, and hydrogen peroxide. Oxidant exposures (CTs) were calculated via decay rates according to Equation (1) with the rates and CTs shown in Table S1 of the Supplementary Materials. The CTs for the five chlorine doses ranged from 6.9-36.7 mg-min/L. The two highest ozone exposures were $2.15-2.94 \mathrm{mg}-\mathrm{min} / \mathrm{L}$, but given the 
immediate decay of ozone, doses of 0.5 and $1 \mathrm{mg} / \mathrm{L}$ (at $5 \mathrm{~min}$ ) had nominal CTs of $0 \mathrm{mg}-\mathrm{min} / \mathrm{L}$. Potassium permanganate was dosed at 2 and $5 \mathrm{mg} / \mathrm{L}$ for $120 \mathrm{~min}$ or CTs of 172 and $456 \mathrm{mg}$-min/L and hydrogen peroxide was dosed at 5 and $10 \mathrm{mg} / \mathrm{L}$ for $6 \mathrm{~h}$ or CTs of 837 and $2168 \mathrm{mg}-\mathrm{min} / \mathrm{L}$. The impact of this oxidation on the fraction of viable vs. injured/dead cells (as determined with flow cytometry) as compared to the cell numbers is shown in Figure 1. Across all oxidants, the control sample initially contained $4 \times 10^{5}$ cells/mL split equally between the Microcystis and Dolichospermum.

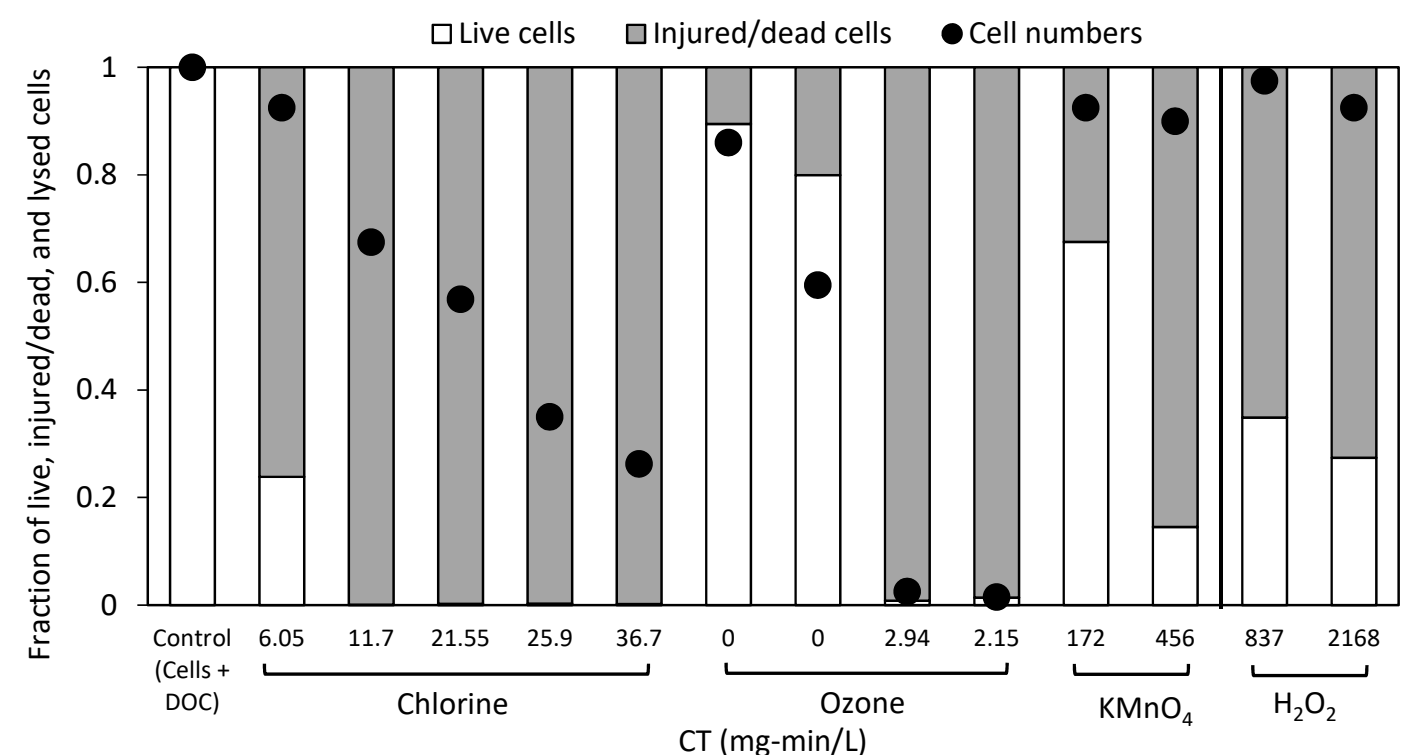

Figure 1. Impact of chlorine, ozone, potassium permanganate, and hydrogen peroxide on the fraction of viable vs. injured/dead cells and cell numbers. The control sample contained $4 \times 10^{5}$ cells $/ \mathrm{mL}$ of Microcystis and Dolichospermum in Lake Champlain water. Viable vs. injured/dead cell concentrations were determined with flow cytometry.

For chlorine, $24 \%$ of the cells remained viable at a CT of $6.9 \mathrm{mg}-\mathrm{min} / \mathrm{L}$, whereas the cell count had only dropped to $98 \%$. CTs of $11.7-36.7 \mathrm{mg}-\mathrm{min} / \mathrm{L}$ all had less than $1 \%$ viable cells, but the cell numbers continued to decrease until they reached $26 \%$, at which point $2 \times 10^{4}$ cells $/ \mathrm{mL}$ of Dolichospermum and $7 \times 10^{4}$ cells $/ \mathrm{mL}$ of Microcysis remained (Figure 1). In order to compare results with previous work, a rate of cell lysis was calculated from the cell counting results according to pseudo first-order reaction kinetics (Equation (2)) and found to be $53 \mathrm{M}^{-1} \mathrm{~s}^{-1}\left(\mathrm{R}^{2}=0.91\right)$ and $24 \mathrm{M}^{-1} \mathrm{~s}^{-1}\left(\mathrm{R}^{2}=0.90\right)$ for Dolichospermum and Microcystis, respectively. The efficacy of chlorine here was similar to previous work in the both CT required (7-29 $\mathrm{mg}-\mathrm{min} / \mathrm{L})$ and the lysis rates $\left(30-170 \mathrm{M}^{-1} \mathrm{~s}^{-1}\right.$; $\mathrm{pH}$ 7-8.6 with $5-20 \times 10^{4}$ cells $/ \mathrm{mL}$ in surface waters) with differences attributed to the $\mathrm{pH}$, specific background organic matter, and the presence of mixed species [20,24,29].

With ozone doses of 0.5 and $1 \mathrm{mg} / \mathrm{L}$, cell viability was reduced by 10 and $20 \%$ and cell numbers decreased to 3.4 and $2.4 \times 10^{5}$ cells $/ \mathrm{mL}$, respectively (Figure 1). At $2 \mathrm{mg} / \mathrm{L}$ for both 5 and $10 \mathrm{~min}$, the cell numbers decreased to $1 \times 10^{3}$ cells $/ \mathrm{mL}$ for Dolichospermum and $5 \times 10^{3}$ cells $/ \mathrm{mL}$ for Microcystis with the total viable cells $<1 \%$. This is in-line with previous work in the absence of background organic matter in which a rapid reduction in cell viability was observed with ozone [17,19-21]. Even with potential scavenging from background organic matter, Zamyadi et al. [26] observed that $90 \%$ of cells were no longer viable following pre-ozonation $(1.2 \mathrm{mg} / \mathrm{L}$, with $20 \mathrm{~min}$ of contact time) of a cyanobacterial bloom in a full-scale water treatment plant.

The two doses of potassium permanganate and hydrogen peroxide saw very limited changes in cell numbers with less than $5 \%$ reduction in Dolichospermum and Microcystis. For potassium permanganate, the flow cytometry results showed that only 67 and $15 \%$ of total cells were viable at 172 and $456 \mathrm{mg}-\mathrm{min} / \mathrm{L}$, respectively. In previous work, without background organic matter, lower CTs were required to achieve $90 \%$ loss of cell viability $[18,20]$. After dosing with hydrogen peroxide, 
viable cells were reduced to $35 \%$ with $5 \mathrm{mg} / \mathrm{L}$ and $27 \%$ with $10 \mathrm{mg} / \mathrm{L}$, but the cell counts remained at $>90 \%$ the original levels. To achieve significant reduction in cell counts, extended contact times and high doses, e.g., $>10 \mathrm{mg} / \mathrm{L}$ and 2 days, were required to produce $80 \%$ lysis of Microcystis [18,37].

The discrepancy between the reduction in cell numbers (generated from cell counting) vs. cell-viability (determined via flow-cytometry) was significantly smaller after ozone relative to chlorine, potassium permanganate and hydrogen peroxide. This is reflective of the type of damage imparted by the oxidant as well as exposure dose. SEM was used to generate images of cells before and after oxidation with ozone, chlorine, and hydrogen peroxide (Figures S1 and S2). Though a very limited data set, these images provide insight into the impact of chlorine, ozone, and hydrogen peroxide on the morphology. Under chlorine ( $37 \mathrm{mg}$ - $\mathrm{min} / \mathrm{L})$ and ozone $(0.5 \mathrm{mg} / \mathrm{L}, 5 \mathrm{~min})$, the cell links between Dolichospermum cells were the first part of the cell damaged whereas hydrogen peroxide $(837 \mathrm{mg}-\mathrm{min} / \mathrm{L})$ shrank and deformed the cells, but fragmentation of the filaments did not occur. Microcystis cells appeared deformed under ozone and chlorine, but not fragmented. These results are similar to those observed in past studies with SEM where ozone and chlorine produced a similar breakup of filaments and deformation of cells [19,38].

As shown with flow cytometry, cell counting and SEM images, ozone produced fragmentation and the release of intracellular material, but potassium chlorine, permanganate and hydrogen peroxide damaged cell walls and viability. This result was further supported by the negligible $(<0.1 \mathrm{mg} / \mathrm{L})$ releases of dissolved organic carbon (DOC) after oxidation with potassium permanganate and hydrogen peroxide relative to the $0.55 \mathrm{mg} / \mathrm{L}$ released after chlorination (max across all CTs) and $1.26 \mathrm{mg} / \mathrm{L}$ after ozonation ( $2 \mathrm{mg} / \mathrm{L}$ with 5 or $10 \mathrm{~min}$ contact times).

\section{2. $L C-O C D-O N D$}

To evaluate the changes in DOC induced by oxidation, the organic matter fractions were determined with LC-OCD-OND. Although cell viability was monitored at multiple CTs, the max CT for each oxidant was used for LC-OCD-OND, i.e., chlorine at $37 \mathrm{mg}$-min/L, ozone at $2.15 \mathrm{mg}$-min/L, potassium permanganate at $456 \mathrm{mg}-\mathrm{min} / \mathrm{L}$, and hydrogen peroxide at $2168 \mathrm{mg}-\mathrm{min} / \mathrm{L}$. From the OCD peaks, the concentration of biopolymers, humic substances, building blocks, low molecular weight (LMW) acids, and LMW neutrals were determined (Figure 2 and Figure S4). Biopolymers include high molecular weight $(>10 \mathrm{kDa})$ polysaccharides, proteins, amino acids, and extracellular polymeric substances. OND provided information regarding the nitrogen content of a subset of the DOC including biopolymer DON, biopolymer N/C ratio, humic substances DON and humic substances N/C ratio. Based on the UVD and the OCD signal, the specific UV absorption (SUVA) at $254 \mathrm{~nm}$ of humic substances was also determined (Table S2). Algal organic matter is generally divided into intracellular organic matter (IOM) and extracellular organic matter (EOM). IOM is primarily composed of proteins, polysaccharides, lipids and humic-like substances [16,39] and Henderson et al. [40] showed that the EOM of Microcystis contains primarily hydrophilic polysaccharides and proteins. 


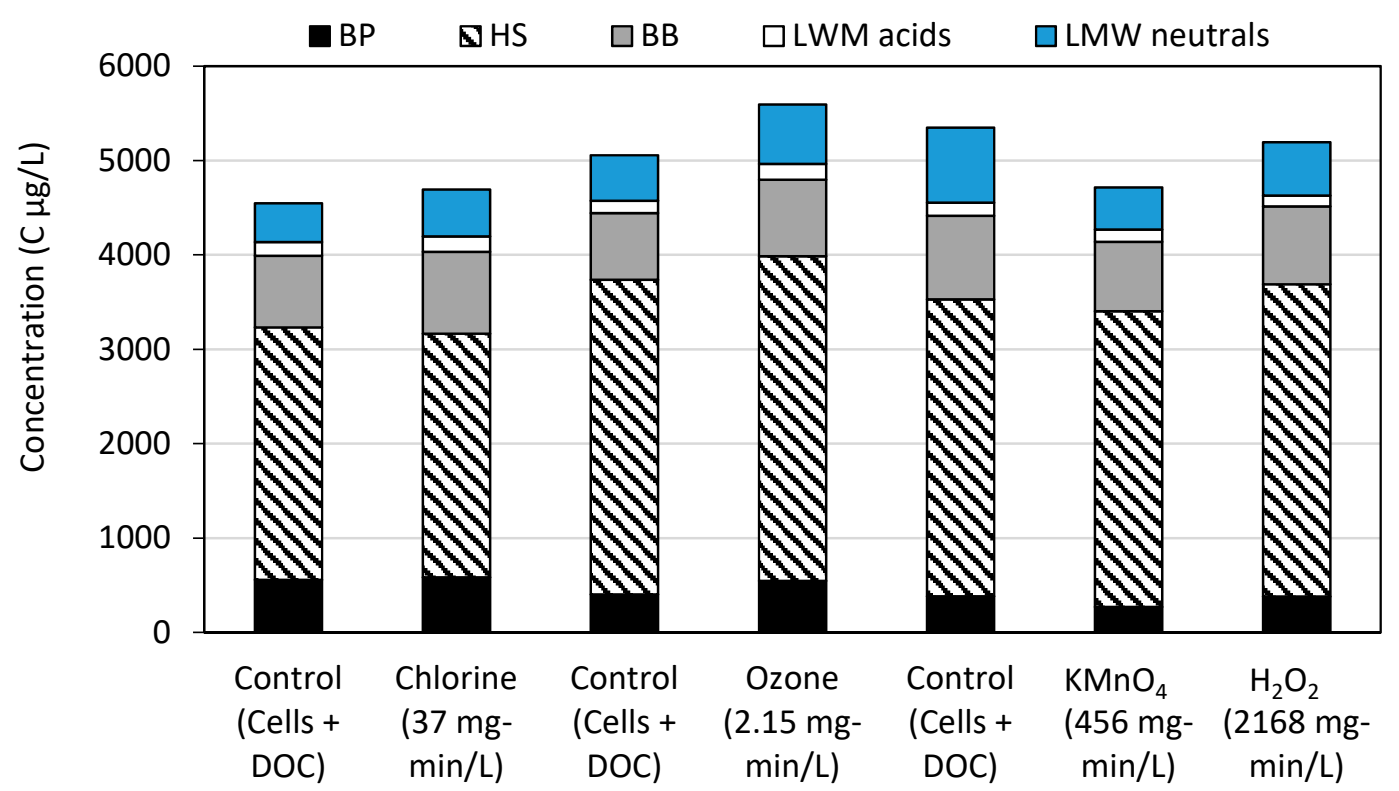

Figure 2. Organic matter fractions before (control) and after the oxidation of Microcystis and Dolichospermum in Lake Champlain water. The three different control samples are the same matrix, conducted as separate experiments. Components were identified via LC-OCD-OND based on Huber et al. [41]: BB = building blocks; HS = humic substances; BP = Biopolymer; LMW = low molecular weight.

The control sample contained both the background organic matter from Lake Champlain and any cell fragments able to pass through the $0.45 \mu \mathrm{m}$ filter (Figure 2). Across all oxidants, humic substances $\mathrm{SUVA}_{254}$ values were lower after exposure due to oxidation reactions with the aromatic sites [42] (Table S2). Decreases of the number-averaged molecular weight of humic substances also occurred across all waters from the breakdown of organic matter present and in the case of ozone, the integration of oxygen resulting in more soluble components [43] (Table S2). The humic substances fraction generally saw minimal change $(<5 \%)$ after oxidation. This was likely due to the background organic matter, which makes up the majority of this fraction and would have been oxidized, but not mineralized at these doses.

Ozonation increased the fraction of humic substances by $3 \%$, biopolymers by $36 \%$, building blocks by $15 \%$, LMW acids by $28 \%$ and LMW neutrals by $31 \%$ (Figure 2 ). Chlorination also increased these fractions, though to a lower extent at $4.8 \%$ for biopolymers, $14 \%$ for building blocks, $13 \%$ for LMW acids, and 20\% for LMW neutrals. Biopolymers likely increased due to the release of IOM, but they may also have come from fragments of the cell membrane or extracellular material (e.g., amino acids, polysaccharides and proteins) [39]. The DON results supported this conclusion as ozonation also increased the concentration of DON biopolymers from 56 to $216 \mathrm{ppb}-\mathrm{N}$ and the ratio of N/C from 0.14 to 0.40 . An important caveat to these results is that the formation of building blocks and LMW acids/neutrals could also have come from the degradation of humic substances.

Potassium permanganate and hydrogen peroxide produced the degradation of all fractions (biopolymer, building blocks, LMW acids/neutrals) and a minor loss of the total carbon, which was attributed to biological consumption during the reaction period (Figure 2). However, DON biopolymers increased in concentration from 10 to 54 ppb-N (after $\mathrm{H}_{2} \mathrm{O}_{2}$ ) and 26 ppb-N (after $\mathrm{KMnO}_{4}$ ) indicative of select IOM release not detected in the bulk DOC. These releases coincided with a change in the fraction of N/C from 0.03 in the control to 0.09 after potassium permanganate and to 0.14 after hydrogen peroxide indicative of the presence of added material from biomass.

The LC-OCD-OND results helped to identify the fractions found in EOM and IOM, which are potential components that could scavenge oxidants and hinder the effective modeling of the oxidation of cyanotoxin and $\mathrm{T} \& \mathrm{O}$ compounds. Although these fractions have been analyzed as a potential source 
of disinfection byproducts and interference to coagulants, they have only been included in a limited set of competition kinetic studies wherein potassium permanganate was scavenged by DOC during the oxidation of cyanotoxins [44].

\section{3. $E D M / H S I$}

The flow cytometry, SEM, and LC-OCD-OND results were compared against the spectra generated with EDM/HSI. EDM/HSI allows for spectra $(400-1000 \mathrm{~nm})$ to be generated from a specific pixel (containing a cell component of interest). In this case, the components of interest for oxidation were the cell wall and cell-bound material for Microcystis and cell wall, cell-bound material, and the links between cells for Dolichospermum. Figure 3 (Dolichospermum) and Figure S3 (Microcystis) are labeled EDM images that show examples of where the cell component spectra were collected. During the experiments, three pixels were selected from each cell component to minimize cell specific variability. The collected spectra were smoothed using a moving average to minimize the noise within the spectra and signal responses were normalized to the maximum value within each spectrum for comparison. EDM/HSI was only conducted for samples oxidized with chlorine (CT of $37 \mathrm{mg}-\mathrm{min} / \mathrm{L}$ ) and ozone $(0.5 \mathrm{mg} / \mathrm{L}$ for $5 \mathrm{~min})$. After this chlorine exposure $(37 \mathrm{mg}-\mathrm{min} / \mathrm{L}),>99 \%$ of cells were not viable and only $26 \%$ of total cells remained from cell counting. The $0.5 \mathrm{mg} / \mathrm{L}$ and $5 \mathrm{~min}$ ozone exposure resulted in a 20 and $40 \%$ reduction in the viable cells and cell numbers, respectively.

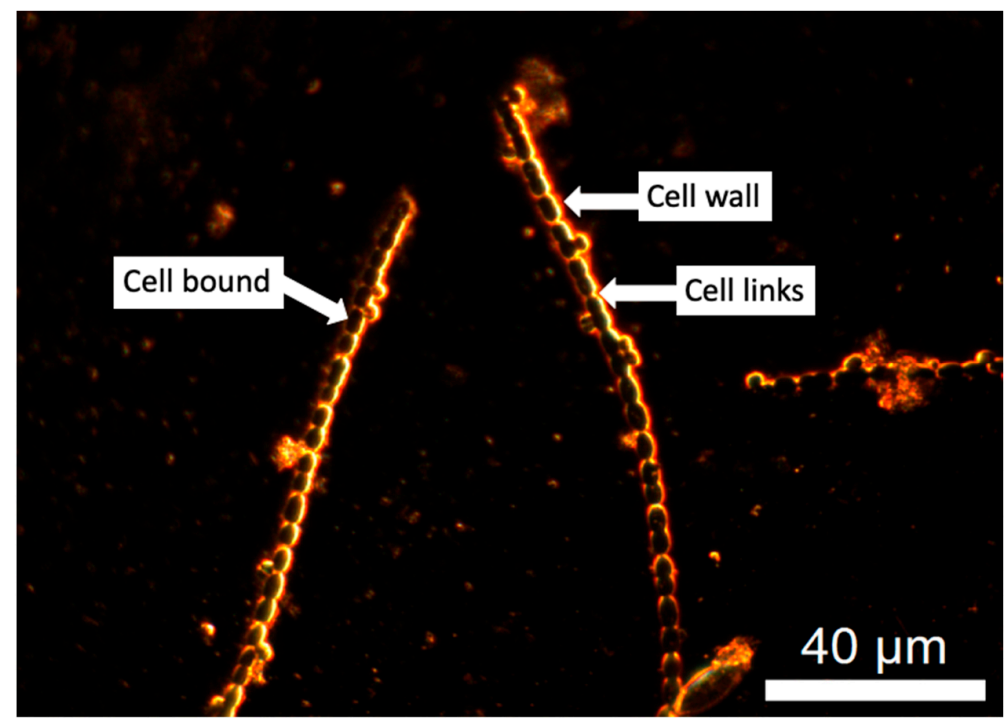

Figure 3. EDM image of Dolichospermum before oxidation, illustrating different pixels targeted for spectral analysis: intracellular or cell-bound material, cell links, and cell wall. The EDM image for Microcystis with labels for intracellular or cell-bound material and cell wall is shown in Figure S3.

The two species had uniquely shaped spectra regardless of cell component (Figures S5 and S6). However, the specific cell components shared common peaks/shoulders for both species, even if the peaks were slightly higher or lower in their maximum wavelength. For Microcystis cells, the spectra had two peaks at approximately 600-650 and 705-715 nm. Dolichospermum had three main features with two peaks at 650-665 and 695-705 $\mathrm{nm}$ and a shoulder at 530-550 nm. For Microcystis, the cell-bound material did not show a dramatic change following chlorination and ozonation (Figure 4a). The ozonated cell-bound material was still dominated by one peak at $\sim 620 \mathrm{~nm}$ and after chlorination, the two cell-bound peaks remained, but a shoulder emerged centered around $\sim 500 \mathrm{~nm}$. In contrast to the cell-bound material, the cell wall spectra were significantly impacted by the two oxidants, showing that both oxidants impact the cell membrane before other components of the cell (Figure $4 \mathrm{~b}$ ). The ozonated cell wall retained a single peak at $660 \mathrm{~nm}$, though significantly broader than the control. The chlorinated 
cell wall produced a new peak at $\sim 500 \mathrm{~nm}$ and the removal of the two peaks originally exhibited by the control sample at $\sim 660$ and $\sim 715 \mathrm{~nm}$.
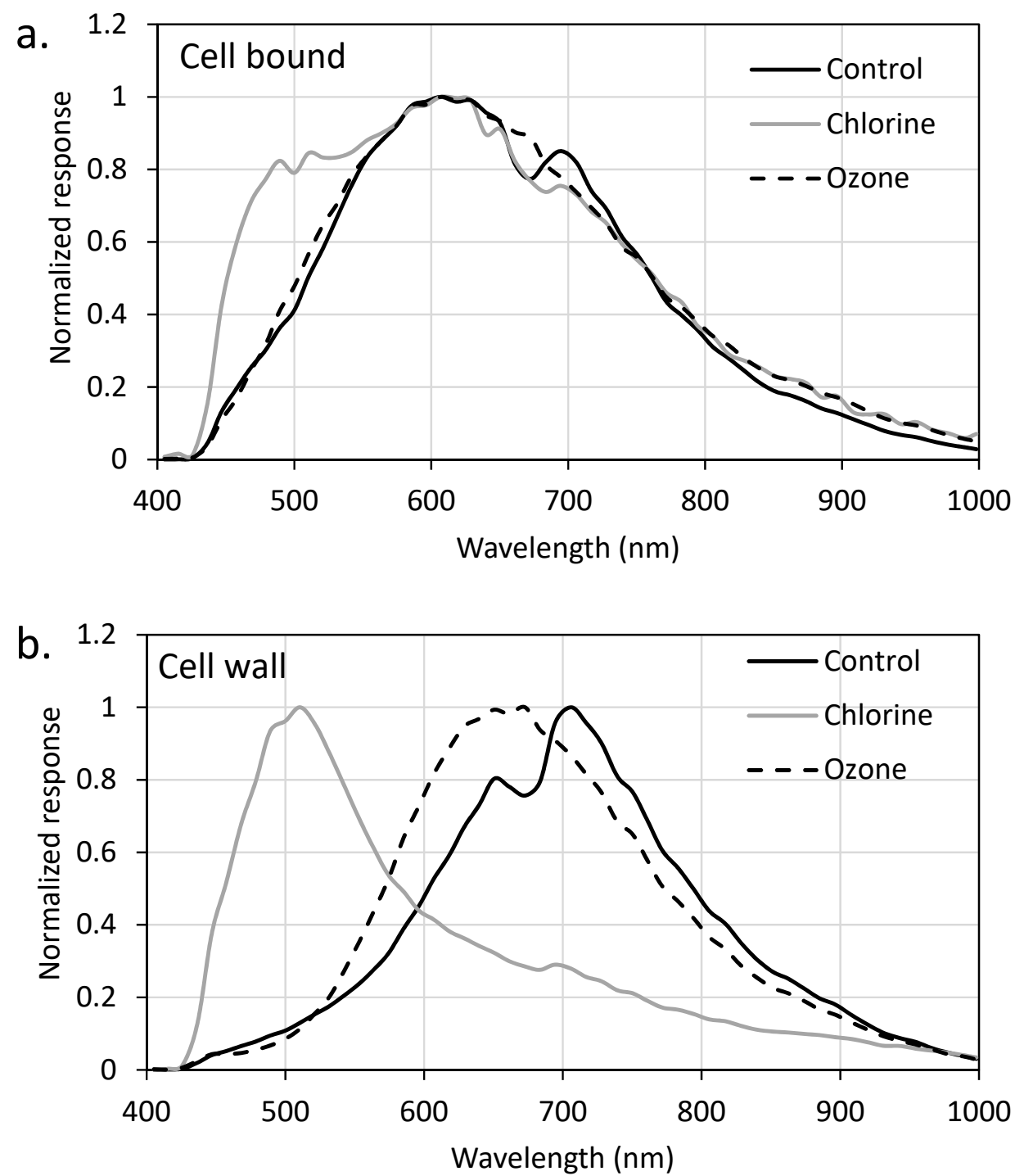

Figure 4. Impact of chlorine $(\mathrm{CT}=37.5 \mathrm{mg}-\mathrm{min} / \mathrm{L})$ and ozone $(0.5 \mathrm{mg} / \mathrm{L}, 5 \mathrm{~min})$ on Microcystis (a) cell-bound material and (b) cell wall. EDM was used to find a pixel containing only the cell-bound material or cell wall where HSI spectra were collected. Instrument responses were normalized to the maximum value of each spectra for comparison.

SEM images of Dolichospermum cells showed that the cell links were targeted first by ozone and chlorine, but the EDM/HSI spectra did not show this result. When the cell links were oxidized (Figure 5c), the ozonated spectra were very similar to the control sample with the same peaks observed. The chlorination of the cell links produced a new shoulder with a max peak around $595 \mathrm{~nm}$, but it smoothed the two other peaks observed in the control. The ozonated cell-bound material retained the two peaks of the control, though the $\sim 660 \mathrm{~nm}$ peak was lower than the $\sim 700 \mathrm{~nm}$ peak; the control shoulder remained, though shifted to lower energy wavelengths ( $550 \mathrm{~nm}$ at max). Chlorination had peaks at $\sim 660$ and $\sim 700 \mathrm{~nm}$, and the shoulder remained intact with a max peak at $\sim 590 \mathrm{~nm}$. For the cell wall, the ozonated water response mirrored those observed in the control at $\sim 520$ nm (shoulder), $\sim 660 \mathrm{~nm}$ (peak), and $\sim 700 \mathrm{~nm}$ (peak). As was observed with Microcystis, chlorine resulted in the formation of a peak centered at $\sim 500 \mathrm{~nm}$, a peak at $\sim 660 \mathrm{~nm}$ and the removal of the peak at $\sim 700 \mathrm{~nm}$. 

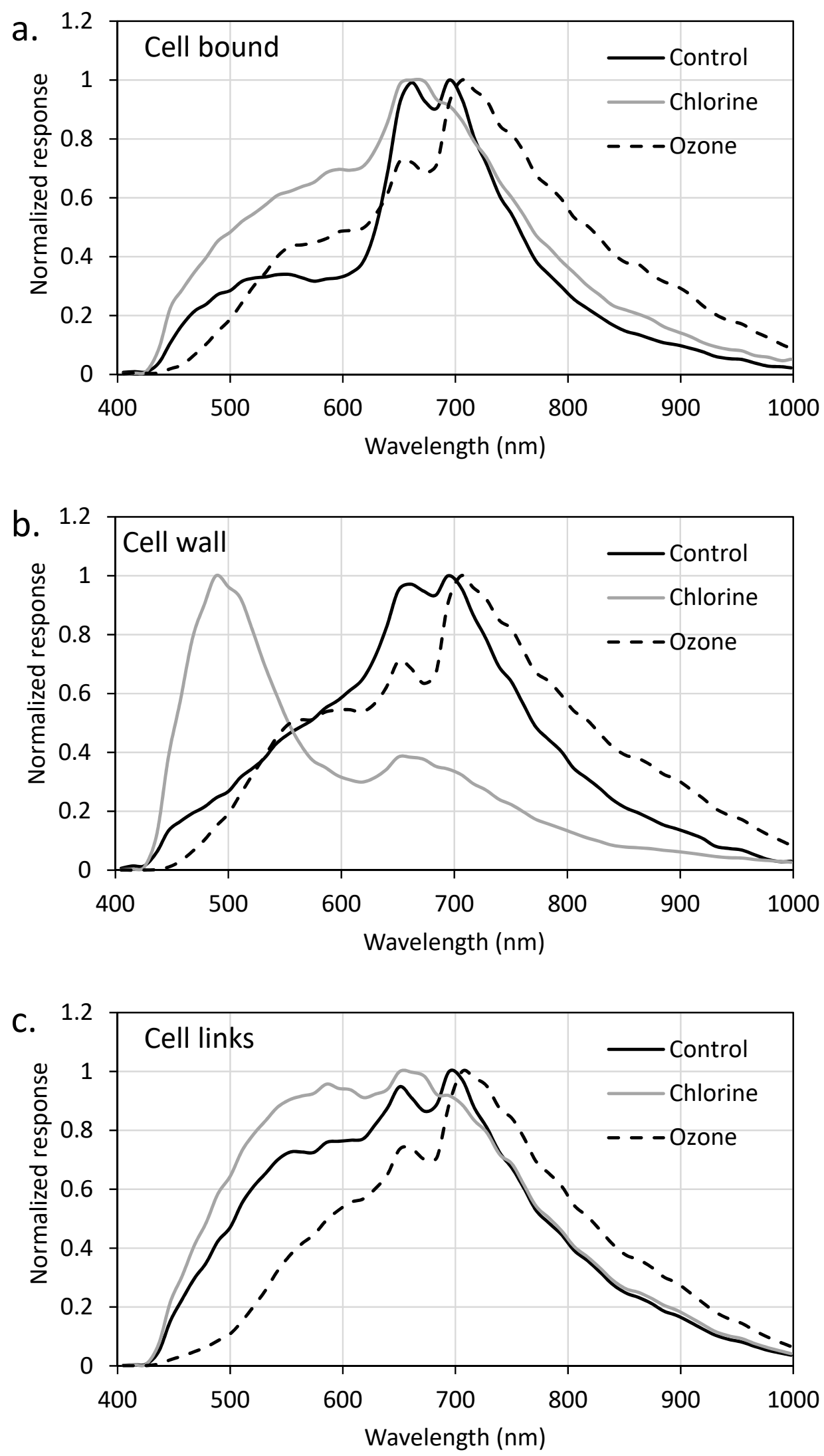

Figure 5. Impact of chlorine (CT $=37.5 \mathrm{mg}-\mathrm{min} / \mathrm{L})$ and ozone $(0.5 \mathrm{mg} / \mathrm{L}, 5 \mathrm{~min})$ on Dolichospermum (a) cell-bound material, (b) cell wall, and (c) cell links. EDM was used to find a pixel containing only the cell-bound material, cell wall, or links between cells where HSI spectra were collected. Instrument responses were normalized to the maximum value of each spectra for comparison. 
The presence of all the peaks identified within these culture samples were likely due to the overlapping absorption of pigments within the cells (e.g., phycocyanin, chlorophyll). The shifts in their absorption to a single peak would appear to indicate a change in the pigments present within the cell wall, cell links or cell-bound material as a result of oxidation. In remote sensing applications, HSI peaks of 620 and $665 \mathrm{~nm}$ were found to corelate with on-the ground levels of phycocyanin and chlorophyll-a, respectively $[34,35]$. The $\sim 700 \mathrm{~nm}$ peak is not used in remote sensing applications because of the interference from water; this interference comes from the application of HSI in reflectance mode as opposed to transmittance mode, which is typically applied at the bench-scale [35]. The differences in spectra shape have been taken advantage of to differentiate between Aphanizomenon flos-aqua and Microcystis at the bench-scale [33], but this was accomplished with a spectral shape algorithm applied to the derivative of the spectrum to obtain meaningful results, which is beyond the scope of this work.

\section{Conclusions}

Flow cytometry and cell counting after oxidation with ozone, chlorine, potassium permanganate and hydrogen peroxide highlighted the discrepancy between cell viability vs. cell lysis and fragmentation. These differences were also observed visually via SEM, which showed the shrinking/deformation of Microcystis and Dolichospermum, but not complete lysis. SEM results also showed the fragmentation of Dolichospermum cell links prior to cell lysis, which has been observed in previous work $[19,30,38]$.

LC-OCD-OND was used to identify the fractions of IOM and EOM released after the oxidation of Microcystis and Dolichospermum in addition to the changes in bulk organic matter from Lake Champlain. Following ozonation and chlorination, increases in the biopolymer fraction were attributed to the release of IOM and potentially fragments of the cell membrane (e.g., amino acids, polysaccharides, and proteins). Future work should aim to better understand how this fraction of released IOM and oxidized EOM impacts the degradation of compounds of interest, e.g., cyanotoxins and T\&O compounds.

EDM/HSI revealed the unique spectra of both the Dolichospermum and Microcystis. Both cultures had spectra with peaks at $\sim 660$ and $\sim 700 \mathrm{~nm}$, but Dolichospermum had a shoulder with a peak at $\sim 550 \mathrm{~nm}$. The oxidation of these cells shifted the responses, which was attributed to the decrease in concentration of pigments present. Both cell wall spectra revealed the formation of a peak after chlorination at $\sim 500 \mathrm{~nm}$, but limited changes were observed following ozonation.

\section{Materials and Methods}

\subsection{Cyanobacteria Culture Sample Preparation}

Microcystis aeruginosa strain CPCC 300 (referred to as Microcystis in the manuscript) and Anabaena sp. strain CPCC 544 (referred to as Dolichospermum in the manuscript due to recent nomenclature changes) were cultured in BG- 11 medium. Cultures were incubated at $21^{\circ} \mathrm{C}$ under a 12 -h rotating light-dark cycle at an intensity of $70 \mu \mathrm{mol} \mathrm{S} \mathrm{S}^{-1}$. Cultures were harvested at stationary phase and spiked into water from Lake Champlain to reach a concentration of $4 \times 10^{5}$ cells $/ \mathrm{mL}$. The Lake Champlain sample was collected from a water treatment plant intake in southern Quebec, Canada in late October and early November of 2018. During this time, the utility measured its intake as having 5-6 mg/L DOC and a $\mathrm{pH}$ of $6.5-7$.

\subsection{Preparation of Oxidants and Calculation of Exposure}

A $2000-\mathrm{mg} / \mathrm{L}$ free chlorine stock solution was prepared from sodium hypochlorite $(5.25 \%)$ on the day of the experiment. The N,N-diethyl-p-phenylenediamine (DPD) colorimetric method was used to measure free chlorine concentration according to Standard Methods (SM) 4500-Cl G [45]. Chlorine doses of 1,2, and $3 \mathrm{mg} / \mathrm{L}$ were added to the two cultures and exposed for 10, 20 and $30 \mathrm{~min}$ of contact time. Samples were exposed at room temperature $\left(22^{\circ} \mathrm{C}\right)$ and chlorine residual measurements were 
taken to estimate oxidant exposure. Samples were quenched sodium thiosulfate at a dose of $1.1 \mathrm{mg} / \mathrm{L}$ per $1 \mathrm{mg} / \mathrm{L}$ chlorine from a stock solution of $3000 \mathrm{mg} / \mathrm{L}$.

An ozone stock solution (50-60 mg/L) was prepared with gaseous ozone using a bench-scale ozone generator (additional details in Zamyadi et al. [21]). Ozone stock concentration and residual ozone in water samples were measured using SM 4500- ${ }_{3}$ [45]. Ozonation experiments were conducted with doses of $0.5,1$, and $2 \mathrm{mg} / \mathrm{L}$ with 5 and $10 \mathrm{~min}$ contact time. Again, samples were quenched with $1.6 \mathrm{mg} / \mathrm{L}$ sodium thiosulfate per $1 \mathrm{mg} / \mathrm{L}$ ozone. Due to the rapid decay of ozone, residuals were below detection for the 0.5 and $1 \mathrm{mg} / \mathrm{L}$ doses.

Potassium permanganate $\left(\mathrm{KMnO}_{4}\right)$ crystals were dissolved in ultrapure water to prepare a stock solution of $5000 \mathrm{mg} / \mathrm{L}$. Experiments were conducted with 2 and $5 \mathrm{mg} / \mathrm{L}$ with $120 \mathrm{~min}$ contact time. Samples were taken at specific times to measure potassium permanganate residual and measured according to the DPD colorimetric method ratio of $0.891 \mathrm{KMnO}_{4} / \mathrm{Cl}_{2} \mathrm{SM} 4500-\mathrm{Cl} \mathrm{G}$ [45]. After $120 \mathrm{~min}$ of contact time, $1.2 \mathrm{mg} / \mathrm{L}$ sodium thiosulfate per $1 \mathrm{mg} / \mathrm{L} \mathrm{KMnO}_{4}$ was used to quench further oxidation.

Hydrogen peroxide $\left(\mathrm{H}_{2} \mathrm{O}_{2}\right)$ stock $(10 \mathrm{~g} / \mathrm{L})$ was prepared from a purchased solution of stabilized hydrogen peroxide (30\%). Cyanobacteria suspensions were dosed with 5 and $10 \mathrm{mg} / \mathrm{L}$ of hydrogen peroxide and exposed for $6 \mathrm{~h}$ of contact time. The hydrogen peroxide residual was measured using a colorimetric test kit (Chemetrics K-5510, Midlands, VA, USA). After the contact time, the residual was quenched with $1.2 \mathrm{mg} / \mathrm{L}$ of sodium thiosulfate per $1 \mathrm{mg} / \mathrm{L} \mathrm{H}_{2} \mathrm{O}_{2}$.

Oxidant exposures (CT) were calculated using Equation (1):

$$
C T=\int_{0}^{t}[\text { Oxidant }] d t=\frac{C_{0}}{k_{\text {decay }}}\left(e^{k_{\text {decay }} t}-1\right)
$$

where $k_{\text {decay }}\left(\mathrm{min}^{-1}\right)$ is the first-order decay rate, $t(\mathrm{~min})$ is the exposure time, and $C_{0}(\mathrm{mg} / \mathrm{L})$ is the initial concentration of oxidant at time zero. CTs for chlorine, ozone, potassium permanganate, and hydrogen peroxide are shown in the Table S1.

CTs were subsequently used to calculate the cell lysis rate:

$$
C=C_{0} \times e^{-k R}
$$

where $C$ was concentration [total cell number (cells $/ \mathrm{mL}$ )] at a given time, $C_{0}$ was the starting concentration [cell number (cells $/ \mathrm{mL}$ ) prior to oxidant exposure], $k$ was the rate $\left[\mathrm{M}^{-1} \mathrm{~s}^{-1}\right.$ ], and $R$ was the oxidant exposure [CT (mg-min/L)].

\subsection{DOC and LC-OCD-OND}

DOC and LC-OCD-OND samples were filtered via a pre-rinsed 0.45- $\mu \mathrm{m}$ membrane (Supor $45 \mu \mathrm{m}$, $47 \mathrm{~m}$, PES PALL, Port Washington, NY, USA) and stored in carbon-free glass vials. A 5310 total organic carbon analyzer (Sievers Analytical Instruments, Boulder, CO, USA) was used to measure DOC. LC was coupled with OCD, OND, and UVD $(254 \mathrm{~nm})$ to track the DOC, DON, and UV responses over chromatographic retention times with various peaks identified and integrated according to Huber et al. [41]. From the LC-OCD, the concentrations of biopolymers (e.g., high molecular weight $(>10 \mathrm{kDa}$ ) polysaccharides, proteins, amino acids, and other components in extracellular polymeric substance), humic substances, building blocks (e.g., low molecular weight humic substances), low molecular weight (LMW) acids, and LMW neutrals were determined. An example chromatogram with labeled peaks can be found in Figure S4. The added data from LC-OND and UVD provided the concentration of biopolymer DON and N/C ratio as well as humic substances DON, N/C ratio, and specific UV absorption (SUVA) at $254 \mathrm{~nm}$. 


\subsection{Cell Counts, Morphology and Integrity}

Cell counts were determined using an inverted microscope in a Sedgwick-Rafter chamber with $20 \times$ magnification on cells preserved with Lugol's Iodine [46,47]. Images of cyanobacteria during oxidation were captured using a SEM (JSM-7600 TFE, JEOL, Akishima, Japan) according to the methods applied in [19]. Cell integrity was determined using flow cytometry (BD Accuri C6 Flow Cytometer, San Jose, CA, USA) and samples were stained with SYBR Green I (SG) and SG propidium iodide to determine total and compromised/dead cells [30,48]. A pre-test with pure cultures (Microcystis and Dolichospermum) was performed to define a suitable gating to differentiate cyanobacteria cells from other bacteria. This modified gating was used in all subsequent flow cytometry analysis.

Sample morphology was analyzed under optical microscope equipped with darkfield illumination and hyperspectral analysis or EDM/HSI (CytoViva, Auburn, AL, USA) [49]. HSI was equipped to monitor wavelengths from 400-1000 nm for every pixel of the image, which was captured at 40X magnification. Pixel sizes were estimated to be $265 \times 265 \mathrm{~nm}$. Quenched samples were put on a microscope slide $(500 \mu \mathrm{L})$ and then dried under the fume hood to avoid the movement of liquid during EDM/HSI. A spot on the slide containing both cyanobacteria species (Microcystis and Dolichospermum) was selected to capture the image and acquire spectral data.

Supplementary Materials: The following are available online at http://www.mdpi.com/2072-6651/11/5/278/s1, Figure S1: SEM images of the cyanobacteria morphology both before and after chlorination (CT of $37.5 \mathrm{mg}-\mathrm{min} / \mathrm{L}$ ): (a) Microcystis in control $(3000 \times)$ (b) chlorinated Microcystis cells $(8500 \times)$, (c) Dolichospermum cells in control (1400×), and (d) chlorinated Dolichospermum cells $(1600 \times)$. Figure S2: SEM image of cyanobacteria after (a) ozonation of both Microcystis and Dolichospermum $(0.5 \mathrm{mg} / \mathrm{L}, 5 \mathrm{~min}$ exposure at $4000 \times)$ and (b) hydrogen peroxide application on Dolichospermum (837 mg-min/L at 2200x). Figure S3: EDM image of un-oxidized Microcystis with cell wall and intracellular material identified. Figure S4: LC-OCD chromatogram of the un-oxidized control cyanobacteria sample. Microcystis and Dolichospermum were spiked into Lake Champlain water and filtered (0.45 $\mu \mathrm{m})$. Figure S5: HSI responses of cell-bound material, cell wall, and cell links for Dolichospermum. Instrument responses were normalized to the maximum value of each spectra for comparison. Figure S6: HSI responses of cell-bound material and cell wall for Microcystis. Instrument responses were normalized to the maximum value of each spectra for comparison. Table S1: First-order decay rates for chlorination and resulting CT. Table S2: Impact of oxidation on organic carbon fractions with LC-OCD-OND-UVD.

Author Contributions: S.M., C.M.G., S.P., B.B., S.D., M.P. and A.Z. conceived and designed the experiments; S.M., J.M., T.Z.S. and S.P., performed the experiments and analysed the samples; S.M., C.M.G., J.M., T.Z.S., S.P., B.B., S.D., M.P. and A.Z. analyzed the data; S.M., C.M.G., J.M., T.Z.S., S.P., B.B., S.D., M.P., A.Z. wrote and edited the paper.

Funding: This research was funded by "Genome Quebec and Genome Canada: Algal Blooms, Treatment, Risk Assessment, Prediction and Prevention through Genomics (ATRAPP) Project", "Natural Sciences and Engineering Research Council of Canada (NSERC) Discovery Grants Program", and "Fonds de recherche du Québec-Nature et technologies (FRQNT) Établissement de nouveaux chercheurs universitaires".

Acknowledgments: The authors gratefully acknowledge support from Algal Blooms, Treatment, Risk Assessment, Prediction and Prevention through Genomics (ATRAPP)—Genome Quebec and Genome Canada, Natural Sciences and Engineering Research Council of Canada (NSERC), and Fonds de recherche du Québec-Nature et technologies (FRQNT). The authors thank the staff at NSERC Industrial Chair on Drinking Water at Polytechnique Montreal. LC-OCD measurements were performed at the NSERC Cahir in Water Treatment at the University of Waterloo by Lin Shen.

Conflicts of Interest: The authors declare no conflict of interest.

\section{References}

1. Anderson, D.M.; Glibert, P.M.; Burkholder, J.M. Harmful algal blooms and eutrophication: Nutrient sources, composition, and consequences. Estuaries 2002, 25, 704-726. [CrossRef]

2. Elliott, J.A. Is the future blue-green? A review of the current model predictions of how climate change could affect pelagic freshwater cyanobacteria. Water Res. 2012, 46, 1364-1371. [CrossRef]

3. Paerl, H.W.; Paul, V.J. Climate change: Links to global expansion of harmful cyanobacteria. Water Res. 2012, 46, 1349-1363. [CrossRef]

4. Watson, S. Aquatic taste and odor: A primary signal of drinking water integrity. J. Toxicol. Environ. Health A 2004, 67, 1779-1795. [CrossRef] [PubMed] 
5. Chernoff, N.; Hill, D.J.; Diggs, D.L.; Faison, B.D.; Francis, B.M.; Lang, J.R.; Larue, M.M.; Le, T.-T.; Loftin, K.A.; Lugo, J.N.; et al. A critical review of the postulated role of the nonessential amino acid, b-N-methylamino-Lalanine, in neurodegenerative disease in humans. J. Toxicol. Environ. Health 2017, 20, 183-229. [CrossRef]

6. Lévesque, B.; Gervais, M.; Chevalier, P.; Gauvin, D.; Anassour-Laouan-Sidi, E.; Gingras, S.; Fortin, N.; Brisson, G.; Greer, C.; Bird, D. Prospective study of acute health effects in relation to exposure to cyanobacteria. Sci. Total Environ. 2014, 466, 397-403. [CrossRef]

7. United States Environmental Protection Agency (U.S. EPA). Recommendations for Public Water Systems to Manage Cyanotoxins in Drinking Water; Office of Water: Washington, DC, USA, 2015; EPA 815-r-15-010.

8. Chorus, I.; Bartram, J. Toxic Cyanobacteria in Water: A Guide to Their Public Health Consequences, Monitoring and Management; World Health Organization (WHO): London, UK, 1999.

9. Health Canada. Cyanobacteria Toxins in Drinking Water. 2016. Available online: https://www.canada.ca/content/dam/canada/health-canada/migration/healthy-canadians/health-systemsysteme-sante/consultations/cyanobacteria-cyanobacterie/alt/cyanobacteria-cyanobacterie-eng.pdf (accessed on 19 February 2019).

10. Zamyadi, A.; MacLeod, S.; Fan, Y.; McQuaid, N.; Dorner, S.; Sauvé, S.; Prévost, M. Toxic cyanobacterial breakthrough and accumulation in a drinking water plant: A monitoring and treatment challenge. Water Res. 2012, 46, 1511-1523. [CrossRef] [PubMed]

11. Zamyadi, A.; Henderson, R.; Stuetz, R.; Hofmann, R.; Ho, L.; Newcombe, G. Fate of geosmin and 2-methylisoborneol in full-scale water treatment plants. Water Res. 2015, 83, 171-183. [CrossRef] [PubMed]

12. Pazouki, P.; Prevost, M.; McQuiad, N.; Barbeau, B.; de Boutray, M.-L.; Zamyadi, A.; Dorner, S. Breakthrough of cyanobacteria in bank filtration. Water Res. 2016, 102, 170-179. [CrossRef]

13. Zamyadi, A.; Dorner, S.; Ndong, M.; Ellis, D.; Bolduc, A.; Bastien, C.; Prévost, M. Low-risk cyanobacterial bloom sources: Cell accumulation within full-scale treatment plants. J. Am. Water Works Assoc. 2013, 102, e651-e663. [CrossRef]

14. Almuhtaram, H.; Cui, Y.; Zamyadi, A.; Hofmann, R. Cyanotoxins and Cyanobacteria Cell Accumulations in Drinking Water Treatment Plants with a Low Risk of Bloom Formation at the Source. Toxins 2018, 10, 430. [CrossRef]

15. Pestana, C.J.; Reeve, P.J.; Sawade, E.; Voldoire, C.F.; Newton, K.; Praptiwi, R.; Collingnon, L.; Dreyfus, J.; Hobson, P.; Gaget, V.; et al. Fate of cyanobacteria in drinking water treatment plant lagoon supernatant and sludge. Sci. Total Environ. 2016, 565, 1192-1200. [CrossRef] [PubMed]

16. Pivokonsky, M.; Naceradska, J.; Kopecka, I.; Baresova, M.; Jefferson, B.; Li, X.; Henderson, R. The impact of algogenic organic matter on water treatment plant operation and water quality: A review. Crit. Rev. Environ. Sci. Technol. 2016, 46, 291-335. [CrossRef]

17. Fan, J.J.; Daly, R.; Hobson, P.; Ho, L.; Brookes, J. Impact of potassium permanganate on cyanobacterial cell integrity and toxin release and degradation. Chemosphere 2013, 92, 529-534. [CrossRef] [PubMed]

18. Fan, J.J.; Ho, L.; Hobson, P.; Daly, R.; Brookes, J. Application of various oxidants for cyanobacteria control and cyanotoxin removal in wastewater treatment. J. Environ. Eng. 2014, 140, 4022-4028. [CrossRef]

19. Coral, L.A.; Zamyadi, A.; Barbeau, B.; Bassetti, F.J.; Lapolli, F.R.; Prévost, M. Oxidation of M. aeruginosa and A. flosaquae by ozone: Impacts on cell integrity and chlorination by-product formation. Water Res. 2013, 47, 2983-2994. [CrossRef] [PubMed]

20. Ding, J.; Shi, H.; Timmons, T.; Adams, C. Release and removal of microcystins from microcystis during oxidative-, physical-, and UV-based disinfection. J. Environ. Eng. 2009, 136, 2-11. [CrossRef]

21. Zamyadi, A.; Coral, L.A.; Barbeau, B.; Dorner, S.; Lapolli, F.R.; Prévost, M. Fate of toxic cyanobacterial genera from natural bloom events during ozonation. Water Res. 2015, 7373, 204-215. [CrossRef]

22. Fan, J.; Rao, L.; Chiu, Y.T.; Lin, T.F. Impact of chlorine on the cell integrity and toxin release and degradation of colonial Microcystis. Water Res. 2016, 102, 394-404. [CrossRef]

23. He, X.X.; Wert, E.C. Colonial cell disaggregation and intracellular microcystin release following chlorination of naturally occurring Microcysis. Water Res. 2016, 101, 10-16. [CrossRef]

24. Zamyadi, A.; Fan, Y.; Daly, R.I.; Prévost, M. Chlorination of Microcystis aeruginosa: Toxin release and oxidation, cellular chlorine demand and disinfection by-products formation. Water Res. 2013, 47, 1080-1090. [CrossRef]

25. Jones, C.T. Determination of the kinetic constants of two consecutive first-order reactions. Biochem. J. 1970, 118, 810-812. [CrossRef] 
26. Zamyadi, A.; Romanis, C.; Mills, T.; Neilan, B.; Choo, F.; Coral, L.A.; Gale, D.; Newcombe, G.; Crosbie, N.; Stuetz, R.; et al. Diagnosing water treatment critical control points for cyanobacterial removal: Exploring benefits of combined microscopy, next-generation sequencing, and cell integrity methods. Water Res. 2019, 152, 96-105. [CrossRef]

27. Zhang, H.; Dan, Y.; Adams, C.D.; Shi, H.; Ma, Y.; Eichholz, T. Effect of oxidant demand on the release and degradation of Microcystin-LR from Microcystis Aeruginosa during oxidation. Chemosphere 2017, 181, 562-568. [CrossRef]

28. Zamyadi, A.; Henderson, R.K.; Stuetz, R.; Newcombe, G.; Newtown, K.; Gladman, B. Cyanobacterial management in full-scale water treatment and recycling processes: Reactive dosing following intensive monitoring. Environ. Sci. Water Res. Technol. 2016, 2, 362-375. [CrossRef]

29. Daly, R.I.; Ho, L.; Brookes, J.D. Effect of chlorination on Microcystis aeruginosa cell integrity and subsequent microcystin release and degradation. Environ. Sci. Technol. 2007, 41, 4447-4453. [CrossRef]

30. Wert, E.C.; Dong, M.M.; Rosario-Ortiz, F.L. Using digital flow cytometry to assess the degradation of three cyanobacteria species after oxidation processes. Water Res. 2013, 47, 3752-3761. [CrossRef]

31. Plummer, J.; Edzwald, J.K. Effects of chlorine and ozone on algal cell properties and removal of algae by coagulation. J. Water Supply Res.Technol.-AQUA 2002, 51, 307-318. [CrossRef]

32. Huang, W.-J.; Cheng, B.-L.; Hu, S.-K.; Chu, C. Ozonation of Algae and Odor Causing Substances in Eutrophic Waters. J. Environ. Sci. Health Part A 2007, 41, 1587-1605. [CrossRef]

33. Paine, E.C.; Slonecker, E.T.; Simon, N.S.; Rosen, B.H.; Resmini, R.G.; Allen, D.W. Optical characterization of two cyanobacteria genera, Aphanizomenon and Microcystis, with hyperspectral microscopy. J. Appl. Remote Sens. 2018, 12. [CrossRef]

34. Randolph, K.; Wilson, J.; Tedesco, L.; Li, L.; Pascual, D.L.; Soyeux, E. Hyperspectral remote sensing of cyanobacteria in turbid productive water using optically active pigments, chlorophyll a and phycocyanin. Remote Sens. Environ. 2008, 112, 4009-4019. [CrossRef]

35. Simis, S.G.; Peters, S.W.; Gons, H.J. Remote sensing of the cyanobacterial pigment phycocyanin in turbid inland water. Limnol. Oceanogr. 2005, 50, 237-245. [CrossRef]

36. Vincent, R.K.; Qin, X.; McKay, R.M.L.; Miner, J.; Czajkowski, K.; Savino, J.; Bridgeman, T. Phycocyanin detection from LANDSAT TM data for mapping cyanobacterial blooms in Lake Erie. Remote Sens. Environ. 2004, 89, 381-392. [CrossRef]

37. Mikula, P.; Zezulka, S.; Jancula, D.; Marsalek, B. Metabolic activity and membrane integrity changes in Microcystis aeruginosa-new findings on hydrogen peroxide toxicity in cyanobacteria. Eur. J. Phycol. 2012, 47, 195-206. [CrossRef]

38. Lin, T.F.; Chang, D.W.; Lien, S.K.; Tseng, Y.S.; Chiu, Y.T.; Wang, Y.S. Effect of chlorination on the cell integrity of two noxious cyanobacteria and their releases of odorants. J. Water Supply Res. Technol. AQUA 2009, 58, 539-551. [CrossRef]

39. Villacorte, L.O.; Ekowati, Y.; Neu, T.R.; Kleijn, J.M.; Winters, H.; Amy, G.; Schippers, J.C.; Kennedy, M.D. Characterization of algal organic matter produced by bloom-forming marine and freshwater algae. Water Res. 2015, 73, 216-230. [CrossRef]

40. Henderson, R.K.; Parsons, S.A.; Jefferson, B. The impact of differing cell and algogenic organic matter (AOM) characteristics on the coagulation and flotation of algae. Water Res. 2010, 44, 3617-3624. [CrossRef] [PubMed]

41. Huber, S.A.; Balz, A.; Abert, M.; Pronk, W. Characterisation of aquatic humic and non-humic matter with size-exclusion chromatography-organic carbon detection-organic nitrogen detection (LC-OCD-OND). Water Res. 2011, 45, 879-885. [CrossRef] [PubMed]

42. Weishaar, J.L.; Aiken, G.R.; Bergamaschi, B.A.; Fram, M.S.; Fujii, R.; Mopper, K. Evaluation of specific ultraviolet absorption as an indicator of the chemical composition and reactivity of dissolved organic carbon. Environ. Sci. Technol. 2003, 37, 4702-4708. [CrossRef] [PubMed]

43. Hammes, F.; Meylan, S.; Salhi, E.; Koster, O.; Egli, T.; Von Gunten, U. Formation of assimilable organic carbon (AOC) and specific natural organic matter (NOM) fractions during ozonation of phytoplankton. Water Res. 2007, 41, 1447-1454. [CrossRef]

44. Laszakovits, J.R.; MacKay, A.A. Removal of cyanotoxins by potassium permanganate: Incorporating competition from natural water constituents. Water Res. 2019, 155, 86-95. [CrossRef] [PubMed]

45. American Public Health Association (APHA). Standard Methods for the Examination of Water and Wastewater; American Water Works Association, Water Environment Federation: Washington, DC, USA, 2012. 
46. Planas, C.; Guadayol, J.M.; Droguet, M.; Escalas, A.; Rivera, J.; Caixach, J. Degradation of polyethoxylated nonylphenols in a sewage treatment plant. Quantitative analysis by isotopic dilution-HRGC/MS. Water Res. 2002, 36, 982-988. [CrossRef]

47. Baker, P.D.; Fabbro, L.D. A Guide to the Identification of Common Blue-Green Algae (Cyanoprokaryotes) in Australian Freshwaters; Cooperative Research Centre for Freshwater Ecology: Canberra, Australia, 2002.

48. Buskey, E.J.; Hyatt, C.J. Use of the FlowCAM for semi- automated recognition and, enumeration of red tide cells (Karenia brevis) in natural plankton samples. Harmful Algae 2006, 5, 685-692. [CrossRef]

49. Théoret, T.; Wilkinson, K.J. Evaluation of enhanced darkfield microscopy and hyperspectral analysis to analyse the fate of silver nanoparticles in wastewaters. Anal. Methods 2017, 9, 3920-3928. [CrossRef]

(C) 2019 by the authors. Licensee MDPI, Basel, Switzerland. This article is an open access article distributed under the terms and conditions of the Creative Commons Attribution (CC BY) license (http://creativecommons.org/licenses/by/4.0/). 